\title{
Efek Perbedaan Suhu dan Lama Pengasapan terhadap Kualitas Ikan Bandeng (Chanos chanos Forsk) Cabut Duri Asap
}

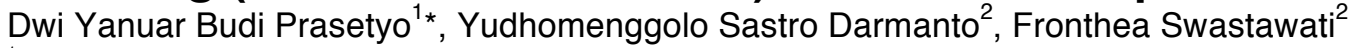

${ }^{1}$ Magister Manajemen Sumber Daya Pantai, Fakultas Perikanan dan Ilmu Kelautan, Universitas Diponegoro, Semarang

${ }^{2}$ Teknologi Hasil Perikanan, Fakultas Perikanan dan IImu Kelautan, Universitas Diponegoro, Semarang

*Korespondensi dengan penulis (yanuarprasetyo87@gmail.com)

Artikel ini dikirim pada tanggal 12 Februari 2015 dan dinyatakan diterima tanggal 4 April 2015. Artikel ini juga dipublikasi secara online melalui

www.journal.ift.or.id. Hak cipta dilindungi undang-undang. Dilarang diperbanyak untuk tujuan komersial.

Diproduksi oleh Indonesian Food Technologists ${ }^{\circledR}$ (C2015 (www.ift.or.id)

\section{Abstrak}

Penelitian ini bertujuan untuk mengetahui pengaruh suhu dan lama waktu pengasapan terhadap kualitas ikan bandeng (Chanos chanos Forsk) cabut duri asap. Ikan bandeng cabut duri dibagi menjadi 9 grup direndam dalam larutan asap cair sekam padi $5 \%$ dan larutan garam 5\% selama 30 menit kemudian ditiriskan pada suhu ruang selama \pm 1 jam. Ikan bandeng yang telah direndam kemudian dimasukkan ke dalam oven dan dipanaskan pada suhu $\left(\mathrm{S} 1=40^{\circ} \mathrm{C}, \mathrm{S} 2=60^{\circ} \mathrm{C}, \mathrm{S} 3=80^{\circ} \mathrm{C}\right)$ selama $(\mathrm{T} 1=1 \mathrm{jam}, \mathrm{T} 2=2 \mathrm{jam}, \mathrm{T} 3=3 \mathrm{jam})$. Data dianalisis menggunakan Analysis of Variance (ANOVA) pada tingkat kerpercayaan $95 \%$. Hasil penelitian menunjukkan suhu dan lamapengasapan memberikan pengaruh nyata $(p<0,05)$ terhadap kualitas ikan bandeng cabut duri asap. Kualitas terbaik didapatkan pada perlakuan $60 \mathrm{C}$ selama 2 jam dengan nilai ketersediaan lisin 2,25\%; kadar air 46,66\%; protein 34,66\%; lemak 10,58\%; abu 2,6\%; pH 5,6; fenol 635 ppm; kenampakan 3,8; warna 3,7; aroma 3,8; rasa 4,7; dan tekstur 4,7.

Kata kunci : suhu, lama pengasapan, kualitas, ikan bandeng cabut duri asap

\section{Pendahuluan}

Pengasapan ikan merupakan salah satu metode pengolahan ikan yang mengkombinasikan proses penggaraman, pemanasan dan pelekatan komponen kimiawi asap. Pengasapan ikan ditujukan untuk pengawetan, akan tetapi peran tersebut kini telah bergeser ke arah pembentukan flavour, warna dan aroma khas ikan asap. Peran tersebut lebih mudah diterapkan apabila menggunakan metode pengasapan ikan dengan asap cair. Asap cair mempunyai beberapa keuntungan seperti mudah penerapan dan pengontrolan untuk menghasilkan produk yang seragam. Bahan baku yang dapat digunakan untuk membuat asap cair di Indonesia adalah sekam padi, karena mudah diperoleh (Swastawati, F. et al. 2014; Swastawati, F. et al. 2012; Martuscelli, 2009; Martinez, 2007).

Ikan bandeng merupakan salah satu produk perikanan yang mempunyai nilai nutrisi tinggi dan dibutuhkan oleh tubuh seperti protein $(20,53 \mathrm{~g} / 100 \mathrm{~g})$ dan asam amino essensial dominan yaitu lisin $(1,886 \mathrm{~g} / 100$ g) (United States Department of Agriculture, 2014). Pengasapan ikan bandeng merupakan salah satu usaha untuk meningkatkan nilai tambah produk dikarenakan perubahan flavour, warna dan aroma khas pada ikan asap sehingga menjadikan tingkat penerimaan produk semakin meningkat.

Faktor penting dalam penentuan kualitas pengasapan ikan adalah suhu dan lama pengasapan. Pemanasan dapat meningkatkan atau menurunkan fungsi dan karakter protein tergantung dari proses pengolahannya, seperti pemanggangan menurunkan asam amino essensial (khususnya lisin) pada ikan rainbow trout, pengasapan menjadikan perubahan warna, kenampakan dan konsisten daging yang menarik pada daging akan tetapi menyebabkan penurunan komponen protein yang signifikan (Yun Deng et al., 2014; S.N, El and A, Kavas. 1996;
Okonwko, T.M. et al., 1992). Pengujian kualitas ikan bandeng asap ditentukan berdasarkan parameter ketersediaan lisin, nilai proksimat (kadar air, protein, lemak, abu dan karbohidrat), $\mathrm{pH}$, fenol dan uji kesukaan atau hedonic test. Lisin merupakan asam amino essensial pembatas pada ikan dan bersifat sangat reaktif selama proses pengolahan (Swastawati, F. et al., 2012). Analisa Proksimat seperti kadar air, protein, lemak, abu, dan karbohidrat sering diperlukan untuk memastikan komponen tersebut pada produk yang diolah masih dalam kisaran kebutuhan makanan dan spesifikasi secara komersil (Oguzhan, $\mathrm{P}$ and Simay, $\mathrm{A}$. 2013). Fenol merupakan salah satu indikator kualitas ikan asap, komponen fenol berperan sebagai flavour, bakteriostatik dan antioksidan (Swastawati, F. et. al., 2014).

Penelitian ini bertujuan untuk mengkaji pengaruh suhu dan lama waktu pengasapan yang berbeda terhadap kualitas (ketersediaan lisin, kadar air, lemak, abu, karbohidrat, $\mathrm{pH}$, fenol, dan hedonic) ikan bandeng asap cabut duri menggunakan asap cair sekam padi. Penelitian ini diharapkan dapat menyediakan informasi dalam bidang pengolahan ikan asap yang mempunyai kualitas tinggi dan dapat diterima konsumen.

\section{Materi dan Metode}

Materi penelitian antara lain ikan bandeng cabut duri segar $( \pm 240-260 \mathrm{gr}, \pm 25 \mathrm{~cm})$. Asap cair sekam padi $(5 \%)$, garam $(5 \%)$. Sedangkan alat yang digunakan adalah oven mekanik $\left(0-150^{\circ} \mathrm{C}\right)$, Spektrofotometer, labu Kjeldhal, Soxhlet, pH meter (Hanna Instrument), score sheet uji hedonic.

\section{Pembuatan Bandeng Asap}

Proses pembuatan ikan asap mengacu pada (Swastawati, F. et al. 2012) dan telah dilakukan modifikasi. Ikan bandeng cabut duri segar direndam dalam larutan asap cair sekam padi $5 \%(500 \mathrm{~mL}$ asap 
cair sekam padi dalam $950 \mathrm{~mL}$ air) dan ditambahkan garam 5\% (5 gr dalam $950 \mathrm{~mL}$ air) selama 30 menit. Ikan ditiriskan dalam suhu ruang selama $( \pm 1$ jam $)$ kemudian dioven pada berbagai kondisi $\left(S_{1} T_{1}=40\right.$ $50^{\circ} \mathrm{C}$ selama $\left.1 \mathrm{jam}\right),\left(\mathrm{S}_{1} \mathrm{~T}_{2}=40-50^{\circ} \mathrm{C}\right.$ selama $\left.2 \mathrm{jam}\right)$, $\left(\mathrm{S}_{1} \mathrm{~T}_{3}=40-50^{\circ} \mathrm{C}\right.$ selama $\left.3 \mathrm{jam}\right),\left(\mathrm{S}_{2} \mathrm{~T}_{1}=60-70^{\circ} \mathrm{C}\right.$ selama $1 \mathrm{jam}),\left(\mathrm{S}_{2} \mathrm{~T}_{2}=60-70^{\circ} \mathrm{C}\right.$ selama $\left.2 \mathrm{jam}\right),\left(\mathrm{S}_{2} \mathrm{~T}_{3}=60-70^{\circ} \mathrm{C}\right.$ selama $3 \mathrm{jam}),\left(\mathrm{S}_{3} \mathrm{~T}_{1}=70-80^{\circ} \mathrm{C}\right.$ selama $\left.1 \mathrm{jam}\right),\left(\mathrm{S}_{3} \mathrm{~T}_{2}=\right.$ $70-80^{\circ} \mathrm{C}$ selama $\left.2 \mathrm{jam}\right),\left(\mathrm{S}_{3} \mathrm{~T}_{3}=70-80^{\circ} \mathrm{C}\right.$ selama $\left.3 \mathrm{jam}\right)$. Setelah dioven ikan bandeng asap didinginkan pada suhu ruang selama \pm 1 jam atau hingga benar-benar dingin agar tidak keluar uap air selama dikemas dengan plastik polietilen sebelum dilakukan analisa kualitas di laboratorium.

\section{Analisa Laboratorium}

Ketersediaan lisin dianalisa dengan prinsip penambahan ninhidrin menggunakan spektrofotometri (Day, R.A. and Underwood, A.L. 2010). Analisa proksimat (AOAC, 2006) meliputi kadar air, analisa kadar air prinsipnya menguapkan molekul air bebas yang ada pada sampel. Kadar protein menggunakan metode Kjeldhal. Kadar lemak dianalisa dengan Soxhlet. Kadar abu dianalisa berdasarkan proses pengabuan dalam furnace pada suhu $525^{\circ} \mathrm{C}$ selama 18 jam. Kadar karbohidrat dianalisa berdasarkan perhitungan pengurangan $100 \%$ dari persentasi kadar air, kadar protein, kadar lemak, dan kadar abu).

Fenol dianalisa menggunakan metode titrasi dengan bromometric (AOAC, 2005), sedangkan $\mathrm{pH}$ menggunakan manualprosedur $\mathrm{pH}$ meter (Hanna Instrument). Uji hedonic menggunakan score sheet dengan skala 1 - 5 ( 1 = sangat tidak suka, 2 = tidak suka, 3 = biasa saja, $4=$ suka, $5=$ sangat suka) untuk setiap parameter (kenampakan, warna, aroma, rasa dan tekstur).

\section{Analisa Data}

Data dianalisis menggunakan Analisis Keragaman (ANOVA) untuk parameter ketersediaan lisin, kadar air, protein, lemak, abu, karbohidrat, $\mathrm{pH}$ dan fenol dengan taraf uji kepercayaan $95 \%$ dan diuji lebih lanjut menggunakan Beda Nyata Jujur (BNJ) apabila terdapat perbedaan yang nyata (Hanafiah, 2011). Sementara untuk uji hedonic dianalisa denga uji Kruskal Wallis dengan taraf kepercayaan 95\%. Analisa data dengan menggunakan bantuan software computer SPSS versi 17.

\section{Hasil dan Pembahasan}

Ketersediaan Lisin

Lisin pada ikan bandeng cabut duri segar dan yang telah diasap dapat dilihat pada Grafik 1 . Suhu dan lama pengasapan memberikan pengaruh nyata terhadap ketersediaan lisin ikan bandeng asap $(p<0,05)$. Lisin mengalami peningkatan selama 2 jam pengasapan, hal ini disebabkan karena hilangnya kadar air pada ikan menyebabkan peningkatan kadar proteinnya. Akan tetapi semakin lama ( 3 jam) lisin mengalami penurunan, hal ini disebabkan oleh reaksi Maillard, panas berlebihan yang merusak protein khususnya asam amino lisin dan juga oleh reaksi dengan komponen bahan makanan lainnya (Kolodjzieska, l. et al., 2004; Fayle et al., 2000). Selain itu, penurunan ketersediaan lisin dapat juga disebabkan karena reaksi dengan garam pada saat proses perendaman dan penirisan sebelum proses pengasapan sebagaimana (Sannaveerapa et al., 2004), hilangnya lisisn pada ikan bandeng dikarenakan garam dan pengeringan dengan sinar matahari. Penelitian Swastawati, F. et al. (2012) menunjukkan ikan asap yang diasap menggunakan asap cair tempurung kelapadan bonggol jagung secara berturut-turut sebesar 1,38 dan 1,65.

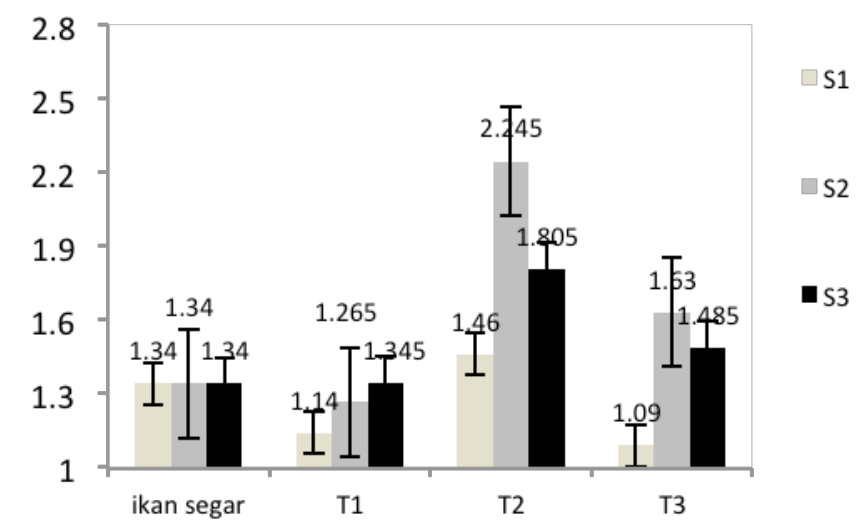

Grafik 1. Nilai rata-rata dari dua kali ulangan ketersediaan lisin ikan bandeng asap (g/100g)

\section{Analisis Proksimat Ikan Bandeng Asap}

Komposisi proksimat ikan bandeng cabut duri segar dan ikan bandeng asap dapat dilihat pada Tabel 1. Nilai yang diikuti huruf yang sama pada tiap parameter menunjukkan tidak berbeda nyata $(p>0,05)$. Perbedaan suhu dan lama pengasapan memberikan pengaruh nyata $(p<0,05)$ terhadap nilai proksimat ikan bandeng asap. Kadar air ikan bandeng segar adalah $69,69 \%$ dan mengalami penurunan dengan semakin tinggi suhu dan lama pengasapan, kadar air pada ikan asap semakin berkurang dikarenakan kadar air bebas yang terkandung pada ikan asap mengalami penguapan sejalan dengan semakin tinggi suhu dan lama pengasapan. Pengurangan kadar air juga dapat disebabkan adanya penambahan garam sebelum dilakukan pengasapan (Swastawati, F. et al., 2014). Hasil penelitian (Oguzhan and Angis, 2013) menunjukkan bahwa kadar air fillet ikan rainbow trout (Onchorhyncus mykiss) yang diasap selama 3 jam dengan suhu $80-90^{\circ} \mathrm{C}$ mengalami pengurangan kadar air sebesar $11,1 \%$ (70,3\% pada fillet segar dan $59,5 \%$ pada fillet asap).

Kadar protein ikan asap mengalami peningkatan pada 1 jam dan 2 jam kemudian mengalami penurunan pada 3 jam pengasapan, hal ini disebabkan peningkatan kandungan Nitrogen sebagai komponen asam amino sejalan dengan hilangnya elemen Hidrogen karena pemasan. Akan tetapi semakin lama pemanasan dapat merusak protein (Mao $\mathrm{L}$ and $\mathrm{Wu}$ Tao. 2008). Pemanasan menyebabkan struktur protein terdenaturasi, terakogulasi dan menjadi bentuk yang 
lebih sederhana. Bentuk yang lebih sederhana dari protein menjadikan protein tidak stabil dan mudah berubah pada kondisi lainnya (Georgiev et al., 2008). Penelitian Akintola, S.L. (2014), menunjukkan bahwa pengasapan berpengaruh nyata terhadap peningkatan makro nutrient terutama protein pada Penaeus notialis (65,76\% pada bahan baku dan $67,00 \%$ pada sampel yang diasap).

Pengasapan juga dapat meningkatkan kadar lemak pada bahan yang diasap, penelitian Yanar et al. (2006), menunjukkan bahwa kadar lemak nila asap (Oreochromis niloticus) tanpa adanya penambahan garam meningkat $0,2 \%$ dari $2,64 \%$ pada ikan segar menjadi $3,14 \%$ setelah diasap. Peningkatan kadar lemak ikan asap dapat dipengaruhi oleh faktor intrinsik maupun ekstrinsik kondisi bahan baku yang digunakan, ikan bandeng tergolong ikan dengan kadar lemak tinggi $(>4 \%)$ sedankan faktor ekstrinsik dapat disebabkan oleh panas dan pelekatan komponen asap cair yang dapat bereaksi dengan enzim pada jaringan ikan menjadikan peningatan laju perubahan kadar lemak (Stolyhwo and Sikorski, 2005).

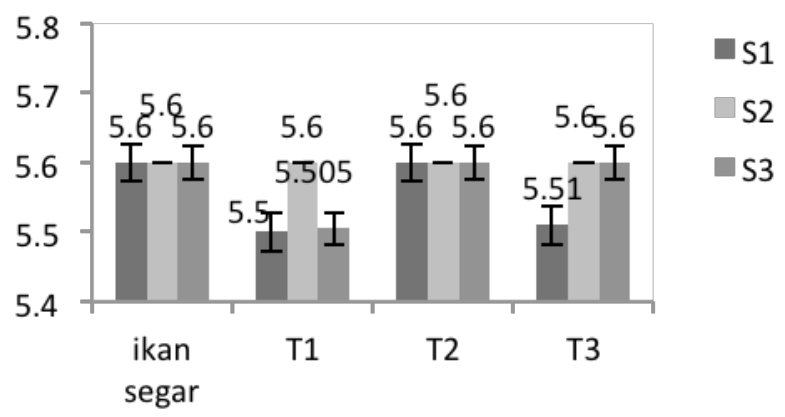

Grafik 2. Nilai rata-rata $\mathrm{pH}$ pada asap cair sekam padi dan bandeng asap

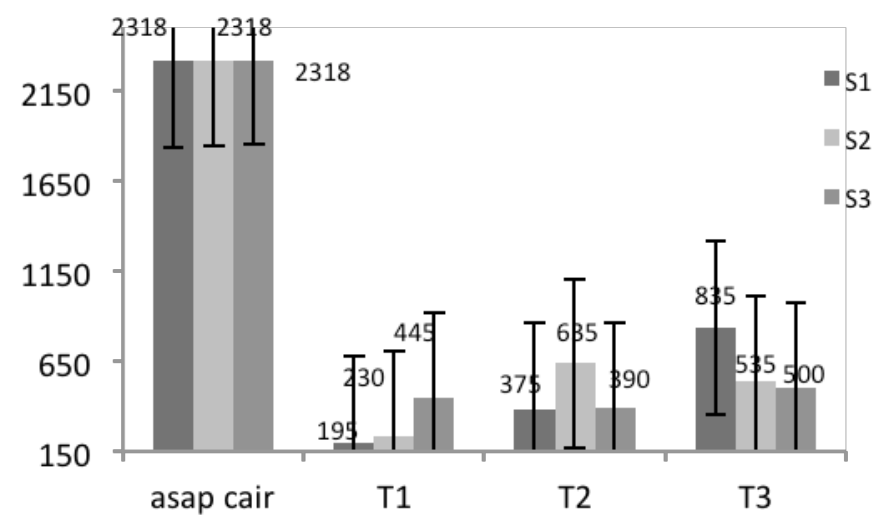

Grafik 3. Nilai rata-rata Fenol (ppm) pada asap cair sekam padi dan bandeng asap

Penentuan kadar abu ditujukan untuk menilai kandungan mineral dalam makanan, apakah masih tersedia atau tidak karena dan sebagai parameter nilai gizi makanan. Suu dan lama pengasapan memberikan pengaruh nyata $(p<0,05)$ terhadap kadar abu ikan asap. Semakin lama pengasapan menyebabkan hilangnya elemen organik seperti Carbon penyusun protein dan lemak serta beberapa Sulfur dan Fosfor pada protein. Penelitian Swastawati, F. (2005), kadar abu ikan kembung asap menggunakan asap cair sekam padi adalah 2,38\%, sementara penelitian Agbabiaka et al. (2012), kadar abu ikan manyung asap (Arius thallasinus) yang di asap selama 4 jam sebesar 2,34\%. Pengasapan juga dapat meningkatkan karbohidrat ikan asap, tetapi nilai karbohidrat yang diperoleh pada penelitian ini $\left(S_{3} T_{3}\right)$ didapatkan dari hasil rumus perhitungan bukan berdasarkan analisa secara laboratorium secara kuantitatif maupun kualitatif.

\section{Nilai pH Ikan Bandeng Asap}

Suhu dan lama pengasapan memberikan pengaruh nyata $(\mathrm{p}<0,05)$ terhadap nilai $\mathrm{pH}$ ikan bandeng asap.Penurunan nilai $\mathrm{pH}$ disebabkan oleh penyerapan senyawa asam seperti asam asetat, dan asam formiat pada asap cair sementara $\mathrm{pH}$ asap cair sekam padi yang dihasilkan adalah 3,8 (Grafik 2). Penelitian Suprayitno et al. (2000), menunjukkan bahwa asap cair dari kayu akasia mempunyai asam organik tinggi sehingga menjadikan penurunan niai $\mathrm{pH}$ pada ikan belut asap. Sementara (Martinez et al., 2007), peguapan yang terjadi pada ikan asap menyebabkan penurunan nilai $\mathrm{pH}$ karena penyerapan senyawa asam yang terkandung pada asap dan reaksi antara fenol, polifenol dengan senyawa karbonil pada protein.

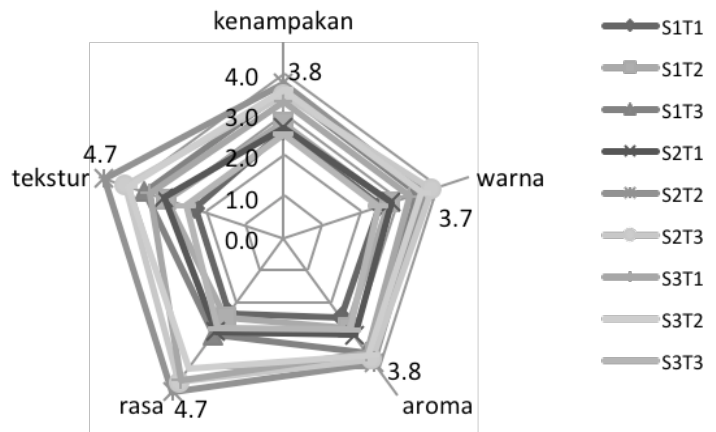

Gambar 4. Nilai rata-rata uji hedonic ikan bandeng asap

Fenol Ikan Bandeng Asap

Fenol merupakan indikator penting pada ikan asap, fenol maupun komponennya berperan penting dalam membentuk citarasa dan aroma khas produk asap yang disukai konsumen (Kostyra and Pikielna, 2006). Suhu dan lama pengasapan memberikan pengaruh nyata $(p<0,05)$ terhadap kadar fenol ikan bandeng asap. Semakin lama pengasapan semakin banyak komponen fenol pada asap yang terserap pada daging ikan (Grafik 3). Birkeland et al. (2004), kadar fenol pada fillet salmon yang diasap dengan pengasapan dingin $\left(22-23^{\circ} \mathrm{C}\right)$ selama 300 menit sebesar $0,82 \mathrm{mg}$ fenol/ $100 \mathrm{~g}$, sementara hasil penelitian Swastawati (2005), kadar fenolkembung asap yang diasap selama 3 jam pada kisaran suhu 50$80^{\circ} \mathrm{C}$ sebesar $52,30 \mathrm{mg} / \mathrm{Kg}$. 
Tabel 1. Komposisi proksimat (\% berat kering)

\begin{tabular}{|c|c|c|c|c|c|c|}
\hline Sampel & Kadar Air & $\begin{array}{l}\text { Kadar } \\
\text { Protein }\end{array}$ & Kadar Lemak & Kadar Abu & Karbohidrat & $\begin{array}{l}\text { Energi } \\
\text { (cal/100gr) }\end{array}$ \\
\hline Segar & $69,69 \pm 0,13$ & $19,39 \pm 0,35$ & $9,25 \pm 0,08$ & $1,39 \pm 0,25$ & $0,28 \pm 0,05$ & $289,39 \pm 2,34$ \\
\hline$S_{1} T_{1}$ & $61,18 \pm 0,22$ & $29,32 \pm 0,02^{c}$ & $7,03 \pm 0,06^{b}$ & $2,25 \pm 0,18^{g h}$ & $0,22 \pm 0,03^{\dagger}$ & $189,58 \pm 0,65$ \\
\hline $\mathrm{S}_{1} \mathrm{~T}_{2}$ & $56,68 \pm 0,07$ & $30,79 \pm 0,08^{b}$ & $7,90 \pm 0,06$ & $2,71 \pm 0,07^{\text {defg }}$ & $1,92 \pm 0,02^{\mathrm{a}}$ & $210,35 \pm 0,33$ \\
\hline $\mathrm{S}_{1} \mathrm{~T}_{3}$ & $49,68 \pm 0,14$ & $32,71 \pm 0,11^{a}$ & $12,89 \pm 0,09$ & $3,39 \pm 0,18^{\mathrm{ab}}$ & $1,33 \pm 0,17^{\mathrm{bcd}}$ & $261,44 \pm 0,70^{\mathrm{a}}$ \\
\hline $\mathrm{S}_{2} \mathrm{~T}_{1}$ & $58,69 \pm 0,04$ & $29,70 \pm 0,24^{c}$ & $7,17 \pm 0,06^{b}$ & $2,70 \pm 0,06^{\text {defgh }}$ & $1,74 \pm 0,32^{\mathrm{ab}}$ & $198,42 \pm 0,35$ \\
\hline $\mathrm{S}_{2} \mathrm{~T}_{2}$ & $46,66 \pm 1,54^{\mathrm{ab}}$ & $34,66 \pm 0,12$ & $10,58 \pm 0,01$ & $2,80 \pm 0,25^{\mathrm{de}}$ & $5,30 \pm 0,01$ & $260,27 \pm 0,57^{\mathrm{a}}$ \\
\hline $\mathrm{S}_{2} \mathrm{~T}_{3}$ & $45,28 \pm 0,13^{a b c}$ & $30,59 \pm 0,09^{b}$ & $19,80 \pm 0,01$ & $2,79 \pm 0,04^{\text {def }}$ & $1,54 \pm 0,27^{\mathrm{abc}}$ & $315,74 \pm 0,53$ \\
\hline$S_{3} T_{1}$ & $52,46 \pm 0,17$ & $33,06 \pm 0,04^{a}$ & $10,87 \pm 0,10^{\mathrm{a}}$ & $2,85 \pm 0,21^{\mathrm{cd}}$ & $0,76 \pm 01,0^{\mathrm{e}}$ & $242,46 \pm 0,36$ \\
\hline $\mathrm{S}_{3} \mathrm{~T}_{2}$ & $46,80 \pm 0,10^{\mathrm{a}}$ & $36,79 \pm 0,16$ & $11,64 \pm 0,38$ & $3,29 \pm 0,16^{\mathrm{abc}}$ & $1,48 \pm 0,16^{\mathrm{abcd}}$ & $268,15 \pm 2,13$ \\
\hline $\mathrm{S}_{3} \mathrm{~T}_{3}$ & $44,08 \pm 0,23^{\mathrm{c}}$ & $31,56 \pm 0,26$ & $13,67 \pm 0,16$ & $3,43 \pm 0,14^{\mathrm{a}}$ & $7,26 \pm 0,05^{\mathrm{ef}}$ & $289,39 \pm 2,34$ \\
\hline
\end{tabular}

Keterangan: Nilai merupakan rata-rata dua kali ulangan \pm standar deviasi

\section{Nilai Hedonic Ikan Bandeng Asap}

Panelis lebih menyukai ikan bandeng asap perlakuan $\mathrm{S}_{2} \mathrm{~T}_{2}$ (Grafik 4), kenampakan dan warna yang dihasilkan coklat - kuning keemasan, rasa dan aroma yang enak khas ikan asap. Perubahan rasa dan aroma ikan asap disebabkan oleh senyawa karbonil dan fenol pada asap. Kostyra and Pikielna (2006), senyawa karbonil dan fenol maupun turunannya berkontribusi dalam menentukan warna, rasa, dan aroma khas pada produk yang diasap.

\section{Kesimpulan}

Pengasapan dengan suhu $60-70^{\circ} \mathrm{C}$ selama 2 jam mampu menjaga kualitas dan menghasilkan ikan bandeng asap yang disukai konsumen. Perlu dilakukan penelitian lebih lanjut tentang keamanan pangan pada ikan asap secara in vivo untuk menjamin tingkat keamanan pangan produk apabila dikonsumsi oleh konsumen dalam waktu jangka waktu dekat, menengah maupun lama.

\section{Ucapan Terima Kasih}

Penulis mengucapkan terima kasih kepada Laboratorium Teknologi Hasil Perikanan, Universitas Diponegoro atas kesempatan dan fasilitas yang diberikan.

\section{Daftar Pustaka}

Agbabiaka, L. A., Amadi A. S., Madubuko, C. U., Nwanko, F.C., and Ojukannaiye A. S. 2012. Assessment of nutrients and sensory qualities of brine pre - treated catfish smoked with two different woods. African Journal of Food Science Vol 6 (7). $245-248$.

Akintola, Shehu Latunji. 2014. Effects of smoking and sun-drying on proximate, fatty and amino acids compositions of southern pink shrimp (Penaeus notialis). J. Food Sci Technol. DOI 10.1007/s13197-014-1303-0.

Association of Official Analytical Chemists (AOAC) (2006) Official Methods of Analysis, 18th edn. AOAC Int, Gaithersburg

Association of Official Analytical Chemist. 2005. Official Method of Analysis of The Association of Official
Analytical of Chemist. Arlington, Virginia, USA: Association of Official Analytical Chemist, Inc.

Day, R. A., and Underwood, A.L. 2010. Analisis Kimia Kuantitatif (Edisi Keenam). Erlangga. Jakarta.

Fayle, S.E, J.A. Gerard, L.Simmons, S.J. Meade, E.A. Reid and A.C. Johnston. 2000. Crosslinking of proteins by dehydroascorbic acid and its degradation products. Food Chem, 70, 193 198.

Georgiev. L., Penchev. G., Dimitriv. D., Pavlov. A., 2008. Structural changes in common carp (Cyprinus carpio) fish meat during freezing. Bulgarian J. Of Veterinary Medicine 2 (2) : 131136.

Hanafiah, Kemas ali. 2011. Experimental Design. Rajawali Press. Jakarta.

Kolodziejska, I., Niecikowska, C., Sikorski, E.Z., and Kolakowska, A. (2004). Lipid oxidation and lysine availability in atlantic mackerel hot smoked in mild condition. Bulletin of The Sea Fisheries Institute. $161,15-27$.

Kostyra, Eliza and Pikielna, Nina Barylko. 2006. Volatiles Composition and Flavour Profile Identity of Smoke Flavourings. Food Qualty and Preference 17. pp 85 -95.

Mao, Linchun. and Wu, Tao. 2008. Influence of hot air drying and microwave drying on nutritional properties of Grass Carp (Ctenopharyngodon edellus) fillets. Food Chemistry 110 (2008) 647653.

Martinez, O. , J. Salmerón, M.D. Guillén and C. Casas. (2007). Textural and physicochemical changes in salmon (Salmo salar) treated with commercial liquid smoke flavourings. Food Chemistry. 100. 498 - 503.

M. Martuscelli., P. Pittia., L.M. Casamassima., A.C. Manetta., L. Lupieri., L. Neri. 2009. Effect of intensity of smoking treatment on the free amino acids and biogenic amines occurence in dry cured ham. Food Chemistry 116. $955-962$.

Oguzhan, Pinar and Simay Angis. 2013. Effects of processing methods on the sensory, mineral matter and proximate composition of rainbow trout (oncorhyncus mykiss) fillets. African Journal 
of Food Science and Technology. Vol 4 (4) 7175. ISSN : 2141-5455.

Okonkwo, T. M., Obanu, Z. A., \& Ledward, D. A. (1992). Characteristics of some intermediate moisture smoked meats. Meat Science, 31, 135 - 145.

Sannaveerapa, T., Ammu, K., Jospeh J. 2004. Proteinrelated changes during salting of Milkfis (Chanos chanos). J-Sci Food Agric 84. 863 - 869.

S.N, El and A, Kavas. 1996. Determination of protein quality of rainbow trout (Salmo irideus) by in vitro protein digestibility corrected amino acid score (PDCAAS). Food Chemistry, 55, 221 - 223.

Stolyhwo, A. and Sikorski, ZE. 2005. Polycyclic aromatic hidrocarbons in smoked fish - a critical review. Food Chemistry. $91: 303-311$.

Swastawati, Fronthea., Y.S. Darmanto., L.Sya'rani., K. Rahayu Kuswanto., K.D. Anthony Taylor. 2014. Quality characteristic of smoked skipjack (Katsuwonus pelamis) using different liquid smoke. International Journal of Bioscience, Biochemistry and Bioinformatics. Vol. 4 No 2 March 2014. 94 - 99.
Eko Susanto., Bambang Cahyono., Wahyu Aji Trilaksono., 2012. Quality characteristic and lysine available of smoked fish. PACBEE Procedia 2 (2012) $1-6$. 2005. Some investigation on the quality of smoked mackerel (Rastrelliger $\mathrm{sp}$ ) using various wood waste of liquid smoke. Journal of Coastal Development Vol. 8 Number 3. $201-205$.

United States Department of Agriculture. 2014. National nutrient database for standard reference. www.ndb.nal.usda.gov. [14 Januari 2014].

Yun Deng, Yuegang Wang., Jin Yue., Zhenmin Liu., Yuanrong Zheng., Bingjunn Qjan., Yu Zhong., Yanyun Zhao. 2014. Thermal behavior, microstructure and protein quality of squid fillets dried by far - infrared assisted heat pump drying. Food Control 36, $102-110$.

Yanar, Yasemen., Mehmet Celik., Erhan Akamca. 2006. Effects of brine concentration on shelf-life of hot smoked tilapia (Oreochromis niloticus) stored at $4^{\circ} \mathrm{C}$. Food Chemistry 97 (2006) 244-247. 